\title{
Weganizm a reduktarianizm
}

\section{Wistepp}

Podczas Ogólnopolskiej Konferencji Przestrzenie posthumanizmu i ekologii, odbywającej się w Gnieźnie w dniach 18-19 kwietnia 2018 roku, a zorganizowanej przez Instytut Kultury Europejskiej UAM, wygłosiłem referat $O$ abolicje wegetarianizmu. W wystąpieniu poświęconym typologii postaw związanych z ograniczeniem i wykluczeniem korzystania z produktów zwierzęcych poddałem analizie współczesne definicje wegetarianizmu, weganizmu i reduktarianizmu. Przyglądałem się także różnicom i podobieństwom pomiędzy praktyką wegetarianizmu, weganizmu i reduktarianizmu. W konkluzji rozważań uznałem wegetarianizm za formę reduktarianizmu, ponieważ stanowi on praktykę polegającą na odrzucenia mięsa, przy jednoczesnej akceptacji innych produktów zwierzęcych, takich jak mleko i/lub jajka. W ogólnym rozrachunku, pomimo wykluczenia jednego wybranego produktu, jest formą ograniczenia - redukcji korzystania z produktów zwierzęcych. Postulowałem porzucenie (abolicję) kategorii wegetarianizmu na rzecz przyjęcia bardziej realistycznej, etycznie uzasadnionej i uproszczonej dwuelementowej typologii postaw. Za dwie warte wyróżnienia oraz promowania postawy - również poprzez rozpowszechnienie stosownej praktyki nazewniczej - uznałem: reduktarianizm i weganizm. Ten pierwszy byłby wyraźnym ograniczeniem korzystania z produktów zwierzęcych, ten drugi próbą ich wykluczenia. Moje rozważania kończyła uwaga, że nowa typologia miałaby mniejsze uzasadnienie, gdyby uznać również weganizm za formę reduktarianizmu. Nie odpowiedziałem jednak na pytanie, czy traktowanie w ten sposób weganizmu jest usprawiedliwione. Rozważania zawarte w niniejszym artykule są kontynuacją procesu badawczego związanego ze wspomnianą typologią i próbą zbadania wzajemnych relacji pomiędzy weganizmem i reduktarianizmem.

\section{Wokół definicji reduktarianizmu}

O ile pojęcie weganizmu było już wielokrotnie analizowane w literaturze przedmiotu, również polskojęzycznej, a subtelności jego definicji zaczynają być 
poddawane badaniu coraz śmielej i systematyczniej w ramach studiów nad zwierzętami i studiów nad weganizmem ${ }^{1}$, o tyle pojęcie reduktarianizmu nie doczekało się jeszcze podobnie dużego zainteresowania. Nie powinno to dziwić - pojęcie to (bo przecież nie sama praktyka) jest stosunkowo nowe. Termin ten jest jeszcze słabo rozpowszechniony w środowisku akademickim jako punkt referencyjny rozważań i obiekt badań, podobnie jak nie jest popularny w całym społeczeństwie, a na dodatek jest również wciąż niedookreślony (rzadkość i brak precyzji definicji) i plastyczny (potencjalna zmienność definicji) ${ }^{2}$. Jednak bez próby możliwie precyzyjnej odpowiedzi na pytanie czym jest reduktarianizm, niemożliwe byłoby udzielenie odpowiedzi na pytanie: czy weganizm jest reduktarianizmem.

Z początkiem reduktarianizmu jako praktyki społecznej posiadającej odrębną nazwę jest związana przede wszystkim postać Briana Katemana, instruktora w The Earth Institute Center for Environmental Sustainability (EICES), działającego przy Uniwersytecie Columbia. To on właśnie wymyślił w roku 2014, wraz z Tylerem Altermanem, słowo reducetarianism i jest współtwórcą The Reducetarian Foundation, na której czele stoi do dziś. Jest także redaktorem książki „założycielskiej” ruchu reduktariańskiego, zatytułowanej The Reducetarian Solution ${ }^{3}$, a także książki kucharskiej The Reducetarian Cookbook ${ }^{4}$. Na stronie internetowej organizacji znajdujemy wyjaśnienie: „Reduktarianizm nie jest nowy - my po prostu daliśmy mu nazwę. Wiele rządów państw, wiodących instytucji zdrowia publicznego i niektóre z największych okręgów szkolnych zachęcały do kampanii na rzecz

1. O definicji weganizmu i studiach nad weganizmem, zobacz: Dariusz Gzyra, Studia nad weganizmem - nowy obszar badawczy, „Edukacja Etyczna” 14/2017, s. 13-26. DOI 10.24917/20838972.14.2.

2. Dość wspomnieć, że jeszcze w 2016 roku badając fenomen abolicjonizmu w kontekście relacji człowieka z innymi zwierzętami i szukając śladów pojęcia reduktarianizmu w polskiej literaturze, nie znalazłem ich. Pisałem wówczas: „Nie spotkałem w literaturze przedmiotu polskiego tłumaczenia terminu reducetarianism, zastępowanego czasem innym: lessetarianism. W mniej formalnym obszarze językowym (np. wpisy na internetowych portalach społecznościowych) można spotkać tłumaczenie: reduktarianizm”. Dariusz Gzyra, Odmiany abolicjonizmu. Zarys nowej klasyfikacji, w: Ludzkie, nie-ludzkie, arcyzwierzęce. Animalocentryzm?, red. Joanna Roś, Kamil M. Wieczorek, Wydawnictwo Leimak, Siemianowice Śląskie 2016, s. 111.

3. Brian Kateman (red.), The Reducetarian Solution: How the Surprisingly Simple Act of Reducing the Amount of Meat in Your Diet Can Transform Your Health and the Planet, Penguin Random House, New York 2017. Książka jest zbiorem krótkich esejów wielu autorów i autorek, wśród nich są Richard Wrangham, Dale Peterson, Paul Shapiro, Michael Shermer, Melanie Joy, Marta Zaraska, Carol J. Adams, Peter Singer, Marc Bekoff, Nick Cooney, Ginny Messina, Jeffrey Sachs, Gene Baur, Joel Fuhrman, James McWilliams i Tristram Stuart. Książka zawiera także część z przepisami, a posłowie napisał Mark Bittman.

4. Brian Kateman, The Reducetarian Cookbook: 125 Easy, Healthy, and Delicious Plant-Based Recipes for Omnivores, Vegans, and Everyone In-Between, Hachette Book Group, New York 2018. Warto zauważyć, że książka zawiera wegańskie przepisy, choć oczywiście reduktarianie mogą $\mathrm{z}$ nich (i podobnych) korzystać tylko od czasu do czasu. 
ograniczenia spożycia mięsa lub wcielały je w życie”. Można dodać, że takie ograniczenie było od dawna częścią osobistych praktyk wielu ludzi, a na długo przez powstaniem nazwy reduktarianizm istniało pojęcie semiwegetarianizmu, choć było ono stosunkowo rzadko używane, natomiast często krytykowane jako wewnętrznie sprzeczne. W powyższym cytacie mowa jest o ograniczaniu mięsa jako cesze reduktarianizmu. W rzeczywistości, w publikacjach fundacji znaleźć można dwa odmienne sposoby charakteryzowania reduktarianizmu, węższy i szerszy - wymiennie mówi się o (1) ograniczaniu spożywania mięsa (i tylko mięsa) oraz (2) ograniczaniu produktów zwierzęcych (w tym mięsa, mleka, jajek).

Jakkolwiek trudno sobie wyobrazić, żeby jedna fundacja, nawet założycielska dla ruchu, mogła zmonopolizować globalne rozumienie pojęcia reduktarianizmu, to jednak na tym etapie jego rozwoju należy uznać próby sformułowania definicji przez The Reducetarian Foundation za decydujące dla jego tożsamości, a problemy związane $\mathrm{z}$ ową definicją - za istotne dla rozumienia całego ruchu reduktariańskiego.

\section{Reduktarianizm jako ograniczenie konsumpcji mięsa}

Określenie reduktarianizmu jako ograniczenia konsumpcji wyłącznie mięsa pojawia się przy wielu różnych okazjach w materiałach informacyjnych związanych z fundacją. Mówi o tym nie tylko podtytuł książki Katemana, jej przedmowa, autorstwa krytyka kulinarnego Marka Bittmana, ale i wstęp, szkicujący ideę reduktarianizmu. Opisując początki ruchu, Kateman pisze: „Tyler i ja zorientowaliśmy się, że istniała potrzeba znalezienia określenia na ludzi takich jak my, ludzi, którzy podejmują działania na rzecz ograniczenia swojej konsumpcji mięsa, niezależnie od stopnia tego ograniczenia i jego motywacji”". Tłumacząc, czym jest reduktarianizm, określa go jako „tożsamość, społeczność i ruch. Składa się z jednostek, które angażują się w ograniczenie jedzenia mięsa - czerwonego mięsa, drobiu i owoców morza”, a sama książka ma być źródłem efektywnych „strategii ułatwiających jedzenie mniejszej ilości mięsa"». Podobną charakterystykę reduktarianizmu można znaleźć w treści wielu esejów, które składają się na książkę, ale dla zobrazowania tego faktu wystarczy zauważyć, że w tytułach kilkunastu z nich

5. https://reducetarian.org/faq

6. Brian Kateman, Introduction, w: The Reducetarian Solution...., red. Brian Kateman, s. xv. Jeśli nie zaznaczyłem inaczej, wszystkie tłumaczenia są mojego autorstwa.

7. Brian Kateman, Introduction...

8. Brian Kateman, Introduction... 
mowa jest o mięsie i tylko o mięsie. Na stronie internetowej fundacji ${ }^{9}$ znajdujemy $\mathrm{w}$ wielu miejscach podobne określenie reduktarianizmu. Można więc między innymi przeczytać zachętę do złożenia obietnicy jedzenia mniejszej ilości mięsa przez trzydzieści dni, co jest oznaczone hasztagiem \#lessmeat. Na podstronie umożliwiającej złożenie tej obietnicy czytamy, że „reduktarianin to ktoś, kto wybiera ograniczenie ilości mięsa a swojej diecie”, a „tysiące ludzi wybiera jedzenie mniej mięsa i staje się reduktarianami”. Na podstronie poświęconej tak zwanym Klubom Reduktarian, do zakładania których na uczelnianych kampusach zachęca fundacja, dowiadujemy się, że tworzenie klubów sprzyja „rozwojowi ruchu ludzi, którzy jedzą mniej mięsa”. W innym miejscu czytamy, że „reduktarianie ustanawiają łatwe do ustanowienia, a zatem możliwe do zrealizowania cele, aby stopniowo jeść \#mniejmięsa”. W rekomendacjach znanych osób, których długa lista znajduje się na podstronie poświęconej książce The Reducetarian Solution, znajdujemy między innymi wypowiedzi pisarza Sama Harrisa („zostań »reduktarianinem «i jedz mniej mięsa”), autorki książek kulinarnych Chloe Coscarelli („Dzięki The Reducetarian Solution jest łatwiej niż kiedykolwiek jeść mniej mięsa i zmienić swoje życie!”), dziennikarza kulinarnego Dana Pashmana („Gdybyśmy wszyscy potrafili jeść tylko odrobinę mniej mięsa, niż to robimy teraz, moglibyśmy przyczynić się do rzeczywistej, pozytywnej zmiany”), pisarza A.J. Jacobsa („mniej mięsa to większa szansa, że uda nam się zachować ludzki gatunek") i psychologa żywienia Briana Wansinka („Ograniczenie ilości mięsa, które jemy, będzie samolubnie przynosić korzyść nam samym, bezinteresownie przynosząc korzyść planecie"). W opisie postaci Katemana na podstronie poświęconej wspomnianej książce kucharskiej również znajdujemy wyjaśnienia niepozostawiające wątpliwości. Miał on bowiem wymyślić termin reduktarianizm, aby „opisać kogoś, kto ogranicza konsumpcję mięsa” i zakłada, że „poprzez eliminację przynajmniej dziesięciu procent mięsa z naszej diety uzyskamy wspaniałe korzyści zdrowotne i przyczynimy się do zdrowia planety". Opis fundacji na jej profilu na Instagramie też jest zgodny z opisaną wyżej charakterystyką i brzmi: „Jesteśmy społecznością ludzi zaangażowanych w ograniczenie konsumpcji mięsa, niezależnie od stopnia i motywacji tego ograniczenia"10. Przedstawianie reduktarianizmu jako postawy polegającej na ograniczeniu konsumpcji tylko wybranego produktu zwierzęcego - mięsa, bez (lub niemal bez) jednoczesnego wskazywania na problematyczność moralną, ekologiczną i zdrowotną innych produktów zwierzęcych, nie jest więc

9. Kolejne cytaty tej części artykułu odnoszą do strony internetowej The Reducetarian Foundation - reducetarian.org i różnych podstron tego serwisu. Dla przejrzystości artykułu rezygnuję z podawania w tej części precyzyjnych przypisów odsyłających do podstron. Tam, gdzie istnienie potrzeba, w artykule zaznaczam źródło cytatu, a więc wskazuję konkretny dział strony reducetarian.org.

10. <https://www.instagram.com/reducetarian>. 
sporadyczne w materiałach twórców reduktarianizmu. Przeciwnie, jest stałym elementem polityki informacyjnej fundacji.

\section{Reduktarianizm jako ograniczenie konsumpeji produktów pochodzenia zwierzęcego}

W ramach tej samej polityki informacyjnej znajdujemy na stronie internetowej The Reducetarian Foundation liczne opisy reduktarianizmu rozumianego szerzej - jako świadome ograniczenie różnych produktów zwierzęcych, w tym mięsa. Na stronie głównej natrafiamy na dobrze widoczne wyjaśnienie, że reduktarianizm tworzą osoby, które starają się jeść mniej mięsa, „jak również mniej nabiału i jajek”. Sama fundacja opisana jest jako „narzędzie rozpowszechniania korzyści osobistych, środowiskowych i w dobrostanie zwierząt, związanych z jedzeniem mniejszej ilości produktów zwierzęcych". Również na stronie głównej znajduje się zapewnienie, że pracuje ona na rzecz „zredukowania ilości produktów zwierzęcych konsumowanych przez społeczeństwo, a poprzez to oszczędzenia okrucieństwa zwierzętom gospodarskim, poprawy zdrowia ludzi i ochrony środowiska naturalnego". We wspomnianej wcześniej zachęcie do złożenia obietnicy zmiany swojej diety, inaczej niż na podstronie, znajdujemy formułę nakłaniającą do „jedzenia mniejszej ilości produktów zwierzęcych przez trzydzieści dni”. Fundacja prowadzi również badania naukowe, a ich potrzebę tłumaczy chęcią maksymalizacji wpływu poprzez „rozpoznanie najbardziej efektywnych sposobów ograniczenia społecznej konsumpcji produktów zwierzęcych”. Na jednej z podstron wyjaśniających bardziej szczegółowo misję fundacji możemy przeczytać, że wielkim problemem środowiskowym, etycznym i zdrowotnym, a także związanym z głodem na świecie, jest nadkonsumpcja zwierzęcych produktów rolnych, a nasza kultura „ma obsesję na punkcie konsumpcji mięsa, jajek i nabiału”. Przeciwnie niż na koncie fundacji na Instagramie, jej konto na Facebooku i Twitterze zawiera opis: „Dążysz do jedzenia mniejszej ilości produktów pochodzenia zwierzęcego? Jesteś zatem reduktarianinem". Szeroką charakterystykę reduktarianizmu znajdujemy także we wstępie do książki The Reducetarian Cookbook, napisanym przez Katemana, a zawierającym między innymi Manifest Reduktariański. Wydaje się on ważnym, jeśli nie najważniejszym wskazaniem czym jest reduktarianizm w roku 2018, cztery lata po stworzeniu terminu i rozpoczęciu promocji idei, która stoi za The Reducetarian Foundation oraz coraz większą liczbą organizacji i środowisk jej przychylnych.

Trzeba przy tym zauważyć, że ruch reduktariański jest już międzynarodowy i również w Polsce znaleźć można organizacje, które w mniejszym lub większym stopniu odwołują się do idei reduktariańskich. W grudniu 2017 roku odbyło się 
w Warszawie szkolenie dla aktywistów, prowadzone przez Centre for Effective Vegan Advocacy (CEVA), a współorganizowane przez polski oddział międzynarodowej organizacji ProVeg i stowarzyszenie Otwarte Klatki. Częścią szkolenia było między innymi zapoznanie polskiego środowiska osób działających na rzecz zwierząt z ideą reduktarianizmu, przy czym był on rozumiany w szerszy sposób. W informacji podsumowującej szkolenie czytamy, że „Reduktarianizm polega na ograniczaniu spożycia produktów pochodzenia zwierzęcego czy to w sposób niezależny, indywidualny, czy poprzez wspólne inicjatywy, takie jak na przykład bezmięsne poniedziałki" ${ }^{11}$.

\section{Ewolucja znaczenia terminu „reduktarianizm”}

Narzuca się myśl, że tak wyraźna - i znacząca, nie tylko moralnie, ale i praktycznie - niespójność różnych wersji definicji reduktarianizmu (redukcja mięsa versus redukcja produktów zwierzęcych) jest formą dezinformacji. Jedno z wytłumaczeń takiej sytuacji mogłoby być następujące: zabieg niedookreślenia jest celowy. Znamy go z historii ruchu prozwierzęcego, wiąże się przecież choćby z użyciem i promowaniem terminem „wege". Był on wielokrotnie wykorzystywany jako zbiorczy termin, obejmujący znacząco różne praktyki konsumenckie, a więc wegetariańską i wegańską. Używany był właśnie po to, aby nie komunikować wyraźnie, o jaką dokładnie praktykę społeczną chodzi. W założeniu miał mieć charakter inkluzywny, być formą docenienia, jako sprzymierzeńca, praktyk niebędących weganizmem, ale mających charakter ograniczenia partycypacji w mechanizmie krzywdzenia zwierząt. Być może więc te elementy opisu reduktarianizmu, które nie wspominają o problematyczności innych produktów zwierzęcych poza mięsem, byłyby formą ukłonu w stronę osób, które - podobnie jak wegetarianie - traktują mięso jako specjalny, wyróżniony, szczególnie zły produkt. Przeciwko takiej interpretacji opisywanego niedookreślenia zakresu znaczeniowego terminu „reduktarianizm” przemawia jednak jego historia. Wiele wskazuje na to, że zakres znaczeniowy tego terminu ewoluował w ciągu trzech-czterech lat od momentu jego powstania i upublicznienia. W tej chwili jesteśmy w momencie, kiedy retoryka zawiera jeszcze wyraźną mieszaninę dwóch definicji: węższej - historycznie starszej oraz szerokiej - późniejszej, stopniowo promowanej coraz wyraźniej. Kiedy spojrzymy na archiwalne wersje strony internetowej reducetarian.org ${ }^{12}$, znajdujemy tam potwierdzenie tej hipotezy. W miejscach, które w aktualnej wersji

11. CEVA Warszawa - Szkolenie dla aktywistów, <https://proveg.com/pl/blog/ceva-warszawa-szkolenie-dla-aktywistow $>(31.10 .2018)$.

12. Wersja strony z połowy grudnia 2015 roku jest możliwa do obejrzenia pod adresem $<$ https:// web.archive.org/web/20151216001527/http://reducetarian.org:80> (31.10.2018). 
strony proponują rozszerzoną definicję, w tym jako wyeksponowany komunikat, wyraźnie widać, że zastąpiła ona starszą. I tak, na archiwalnej stronie głównej czytamy, że reduktarianie to ci, którzy ograniczają jedzenie mięsa, a więc „czerwonego mięsa, drobiu, owoców morza i ciał jakichkolwiek zwierząt" - nie ma mowy o jakichkolwiek innych produktach zwierzęcych. W dziale zawierającym odpowiedzi na najczęściej zadawane pytania, mamy natomiast osobne pytanie (nieistniejące w obecnym FAQ) o „inne produkty zwierzęce, jak jajka i mleko”. Odpowiedź wyraźnie wskazuje, że przy ówczesnym rozumieniu reduktarianizmu ich ograniczenie w diecie było zaledwie opcjonalne. Czytamy w niej, że „reduktarianie moga (podkreślenie - D.G.) także zmniejszyć konsumpcję nabiału, jajek i innych produktów zwierzęcych". Historię zmiany definicji możemy prześledzić również na przykładzie obu wspomnianych wcześniej książek związanych z nazwiskiem Katemana. I w tym przypadku mamy do czynienia z widocznym poszerzeniem definicji: od redukcji mięsa do redukcji produktów pochodzenia zwierzęcego. Jak było wspomniane wcześniej, Manifest Reduktariański z książki z 2018 roku nie wyróżnia mięsa jako szczególnie problematycznego.

Przyszłość pokaże, która z definicji ostatecznie się ustali i na jak długo, ale wiele wskazuje na to, że w najbliższym czasie szersza stopniowo zastąpi wcześniejszą, przy czym wciąż okazyjnie będziemy mieli do czynienia z komunikatami odnoszącymi się wyłącznie do mięsa. Zabieg wyróżniania mięsa w próbie zdefiniowana reduktarianizmu można traktować jako próbę dopasowania się do stanu wiedzy i świadomości społecznej co do etycznej, ekologicznej i do pewnego stopnia zdrowotnej problematyczności różnych produktów zwierzęcych. Inaczej mówiąc: dopasowania do wciąż rozpowszechnionej niewiedzy i braku świadomości, że we współczesnym świecie mięso, mleko i jajka (żeby pozostać przy tej podstawowej trójcy) są etycznymi ekwiwalentami. Można też powiedzieć, że powielanie przez środowisko reduktarian komunikatów podkreślających wyjątkową problematyczność mięsa jest utratą możliwości edukacyjnych, utrwalaniem nierealistycznej wizji świata i spychaniem w cień wielu zwierzęcych ofiar. Nawiązując do początku artykułu i rozważań o ewentualnej abolicji wegetarianizmu - można sądzić, że miałaby ona pozytywny wpływ również na kształt reduktarianizmu - nie tylko jego definicję, ale i praktykę. Reduktarianizm utraciłby alibi wegetarianizmu, byłby więc zmuszony definiować się szerzej i komunikować swoje postulaty w sposób lepiej odzwierciedlający realia współczesnej eksploatacji zwierząt.

\section{Reduktarianie a weganizm i weganie}

Gdy piszę o relacjach pomiędzy reduktarianami a weganizmem i weganami/ wegankami, myślę o opiniach formułowanych przez konkretne osoby określające 
się jako reduktarianie lub zwolennicy reduktarianizmu, a dotyczących ich stosunku do wegan i weganizmu, rozumienia reduktarianizmu poprzez jego odniesienie do weganizmu lub tego, co się za niego uważa, a także wątków autobiograficznych związanych $\mathrm{z}$ własnymi przekonaniami i praktykami w kontekście obu pojęć. Jest to inna warstwa relacji niż wzajemne odnoszenie się do siebie definicji reduktarianizmu i weganizmu lub praktyk społecznych stojących za tymi pojęciami a badanych zbiorczo, jako prawidłowości przekonań i zachowań (w tym konsumenckich) w społeczeństwie. Zawartość emocjonalna tych wypowiedzi, siła i charakter retoryki opisującej wegan i weganizm, wskazują, że zbadanie tego rodzaju relacji jest ważne w kontekście pytania o to, czy weganizm można i powinno się uznać za reduktarianizm.

Pisząc o ewolucji swojego sposobu odżywiania, która zaprowadziła go do stworzenia pojęcia reduktarianizmu, Kateman wspomina, że początkowo jego dieta stanowiła typowy przykład Standard American Diet, a więc diety pełnej przetworzonych produktów zwierzęcych. Punktem przełomowym miała być dla niego lektura książki Petera Singera i Jima Masona The Ethics of What We Eat: Why Our Food Choices Matter ${ }^{13}$. Wkrótce po lekturze stał się wegetarianinem "aspirującym do bycia weganinem"14. Miał jednak silne i niewygodne poczucie, że jego wegetarianizm „nie był doskonały”, przez co rozumiał sytuację, w której co jakiś czas jadł „małe ilości produktów zwierzęcych w szczególnie wyjątkowych i skomplikowanych sytuacjach społecznych" ${ }^{15}$. Wspomniana niewygoda wiązała się z poczuciem kryzysu tożsamości. Owo napięcie doprowadziło go do zerwania $\mathrm{z}$ określaniem się mianem wegetarianina i rozpoczęcia procesu poszukiwania terminu lepiej oddającego jego wybory żywieniowe. Proces ten wiązał się z odrzuceniem zasłyszanych przez Katemana określeń, jak cheating vegetarian lub lazy vegan jako zbyt negatywnych i skupiających się raczej na wadach niż na osiągnięciach. Istniały oczywiście określenia, które były odpowiedniejsze i bardziej rozpowszechnione, jak fleksitarianizm (sporadyczne jedzenie produktów zwierzęcych), ale podobnie jak w przypadku mostly vegetarianism i semiwegetarianizmu, zostały przez niego uznane za nieodpowiednie między innymi z tego powodu, że odnosiły się wyłącznie do osób, które już stosowały dietę opartą na roślinach (a więc głównie roślinną). Kateman chciał bowiem znaleźć takie określenie, które nie tylko miało pozytywny wydźwięk, ale było inkluzywne. Miało się odnosić do szerszej grupy - ludzi, którzy „zdecydowali się na ograniczenie ilości produktów zwierzęcych w swojej diecie i którzy chcą

13. Polskie wydanie książki: Peter Singer, Jim Mason (red.), Etyka a to, co jemy, przeł. Elżbieta de Lazari, Wydawnictwo Czarna Owca, Warszawa 2012.

14. Brian Kateman, Introduction, w: The Reducetarian Cookbook..., red. Brian Kateman.

15. Kateman, Introduction... 
zainspirować innych do zrobienia tego samego"16. Z powyższych cytatów jawi się specyficzny obraz weganizmu: w oczach Katemana to coś ekskluzywnego, do czego się aspiruje, ale co trudno osiągnąć, a praktykowany konsekwentnie, podobnie jak wegetarianizm, ma cechę doskonałości (z negatywną konotacją, czasem nawet samozwańczej doskonałości), której utrzymanie jest kłopotliwe i od której odstępstwo kończy się kryzysem tożsamości i poczuciem winy.

Manifest Reduktariański Katemana zawiera cztery punkty - opisują one główne zasady ruchu. Pierwszy z nich krytykuje tendencję postrzegania wyborów żywieniowych jako nieuchronnie opartych na założeniu „wszystko albo nic” - „jesteś weganinem lub wszystkożercą" ${ }^{\prime 17}$. Kateman uważa je za nieprawdziwe. Podkreśla, że każdy z nas dokonuje codziennie wielu wyborów żywieniowych, a każdy posiłek jest kolejną okazją dokonania wyboru. Tych, którzy nie są w stanie za każdym razem wybrać weganizmu, zachęca: „nie bądź zbyt surowy dla siebie, jeśli się potkniesz", ponieważ kolejna okazja dokonania lepszego wyboru już czeka. "Reduktarianie świętują postęp, nie doskonałośc” - pisze Kateman, przywołując również słowa Voltaire’a: „Doskonałe jest wrogiem dobrego”. Mamy tu krytyczną dyskusję z weganizmem rozumianym jako stała, powtarzalna, konsekwentna praktyka, która nosi znamiona niezniuansowanej ogólnej zasady i żąda uniwersalizmu, jest niewrażliwa na kontekst i przecenia bezbłędność, odbierając wartość innym postawom.

W drugim punkcie Manifestu znajdujemy podobne wątki - mowa jest o tym, że stopniowe ograniczanie produktów zwierzęcych jest czymś wartościowym. Skontrastowane jest ono $\mathrm{z}$ „nagłym przejściem na weganizm”, które wymaga stosownej, wyjątkowej motywacji. Kateman powołuje się na badania naukowe, których wyniki potwierdzają zasadę, że stopniowe ograniczanie produktów zwierzęcych sprzyja postępowi procesu coraz większego ograniczania. Przywołuje też własny przykład - stopniowo przeszedł od standardowej diety do weganizmu. Podkreśla potrzebę dostosowania tempa zmiany do własnych możliwości i potrzeb, a presję na jej przyspieszenie widzi jako zagrożenia dla stabilności wyboru. Ze sposobu, w jaki opisany jest w tym punkcie weganizm, wynika sugestia, że preferuje on wymagające rozwiązania binarne - również co do sposobu jego przyjmowania, nie tylko realizacji.

Podczas gdy trzeci punkt stanowi pochwałę różnorodności możliwych motywacji przyjmowania postawy reduktariańskiej - estetycznych, ekologicznych, zdrowotnych i etycznych - w czwartym punkcie znów znajdujemy podkreślenie inkluzywności reduktarianizmu, jako jednoczącego osoby zwiększające stopniowo ilość produktów roślinnych w diecie. Reduktarianizm ma pomagać w skupieniu

16. Kateman, Introduction...

17. Kateman, Introduction... 
się nie na różnicach, a na tym, co wspólne, a co jest przekonaniem o konieczności zakończenia przemysłowego chowu zwierząt oraz znaczącego społecznego ograniczenia konsumpcji produktów zwierzęcych. Reduktarianizm ma być platformą, która łączy większą grupę osób niż tylko wegetarianie i weganie. Na tym tle weganizm rysuje się jako ten, który w sposób nieuzasadniony, niepotrzebny i niekorzystny dzieli grupę osób w rzeczywistości mających wiele wspólnego, przy czym to co, jest im wspólne, stanowi sferę najważniejszych wartości.

Wiele innych wypowiedzi odnoszących się do weganizmu, które znaleźć można w materiałach związanych $\mathrm{z}$ The Reducetarian Foundation, zawiera podobne oceny, sugestie i akcenty. W przedmowie do The Reducetarian Cookbook, znany propagator pseudomedycyny Deepak Chopra powtarza formułę o skupianiu się na postępie, a nie perfekcji. Na stronie internetowej fundacji możemy znaleźć cytat przypisywany Winstonowi Churchillowi, mówiący o tym, że „Doskonałość jest wrogiem postępu”. W długiej litanii rekomendacji towarzyszących The Reducetarian Solution ${ }^{18}$ znajdujemy słowa między innymi pisarza i sceptyka Michaela Shermera, nawiązujące do neologizmu futurysty Kevina Kelly'ego: protopia. Protopijny model postępu moralnego, którego przykładem miałby być reduktarianizm, wyraża się w stopniowych zmianach ku lepszemu, a nie na nacisku na (utopijną i potencjalnie dystopijną) doskonałość - w ten sposób miałaby się dokonać rewolucja ${ }^{19}$. Teoretyk mediów Douglas Rushkoff stwierdza natomiast, że „[s]topniowa zmiana, wprowadzana na szeroką skalę, za każdym razem bije na głowę radykalny utopianizm”. Psycholog Paul Bloom stwierdza, że "próba bycia perfekcyjnym może być paraliżująca”, a biolożka ewolucyjna Alice Roberts nawołuje: „Zapomnij o purytańskich połajankach” i skup się na tym, co praktyczne i wykonalne. Pisarka i dziennikarka Ina Yalof również wpisuje się w podobną retorykę, gdy stwierdza, że „pytanie nie brzmi, czy jeść mięso, czy je porzucić. Kwestia nie jest zupełnie czarno-biała”. Wreszcie, Steven Pinker pozwala sobie na tyleż zgrabną, co ryzykowną uwagę: „Reduktarianizm: $2 \rightarrow 1$ burgerów ratuje tyle krów, co $1 \rightarrow 0$ ".

W opisie założeń reduktarianizmu na stronie internetowej reducetarian.org znajdujemy dodatkowo stwierdzenie, że celem fundacji i ruchu przez nią zapoczątkowanego jest „przełamać izolację i zwiększyć współpracę, rozwijając ruch nieco fragmentaryczny i niszowy, w zwarty i mainstreamowy”. Pojawia się także kolejne podkreślenie stopniowalności postaw - jej wartości i normalności: „Dobra wiadomość jest taka, że dieta to pewne spektrum. Koncepcja reduktarianizmu

18. Znajdują się one zarówno w książce, jak i na stronie internetowej fundacji.

19. Shermer zajmuje się protopią również w kontekście praw zwierząt, zobacz: Michael Shermer, The Moral Arc: How Science Leads Humanity Toward Truth, Justice, and Freedom, Henry Holt and Company, New York 2015. 
przemawia do osób, które mogą nie chcieć radykalnie zmienić swojej diety”. $\mathrm{W}$ tych fragmentach promowane jest skojarzenie weganizmu $\mathrm{z}$ radykalizmem i niszowością, postawą powodującą podziały w środowisku osób na różne sposoby zainteresowanych ograniczeniem korzystania z produktów zwierzęcych i nieposiadającą cechy stopniowalności.

Format niniejszego artykułu nie daje możliwości wyczerpującego odniesienia się do wszystkich elementów opisywanej charakterystyki weganizmu, jednak bez wątpienia można powiedzieć, że niemal każdy z nich daje się w mniejszym lub większym stopniu zakwestionować lub przynajmniej znacznie zniuansować. Z pewnością nie jest to jedyny możliwy sposób postrzegania i opisu weganizmu. Przeciwnie - sprawia on wrażenie zaprojektowanego w sposób, który byłby użyteczny w procesie propagowania reduktarianizmu jako ruchu niewymagającego, bardziej realistycznego i liberalnego co do stopnia zaangażowania. Przedstawienie weganizmu w ten sposób przypomina atakowanie chochoła, fikcyjnej konstrukcji z wyolbrzymionymi i wyróżnionymi negatywnymi cechami, przydatnej jako punkt odniesienia w procesie budowania własnej tożsamości - wedle zasady kontrastu. Jednocześnie trzeba zauważyć, że pomimo powtarzających się w materiałach fundacji takich elementów charakterystyki weganizmu w zbiorze The Reducetarian Solution znajdujemy głosy autorek i autorów, które są bardziej wyważone i przedstawiające weganizm w lepszym świetle. Warto też zauważyć, że książka kucharska wydana przez fundację zawiera wyłącznie wegańskie przepisy.

\section{Wokół definicji weg゚anizmu}

O tym, czym jest weganizm i czy można go uznać za reduktarianizm, decyduje oczywiście nie tylko głos reduktarian i nie wyłącznie definicja reduktarianizmu. Należy również przywołać definicję weganizmu, do której odwołują się sami weganie ${ }^{20}$. Naturalnym wyborem wydaje się klasyczna już definicja zaproponowana w roku 1979 przez The Vegan Society. Według niej weganizm oznacza filozofię i sposób życia, który „dąży do wykluczenia - na ile to możliwe i wykonalne - wszystkich form eksploatacji i okrucieństwa wobec zwierząt pozaludzkich dokonywanych dla potrzeb żywienia, ubrania lub jakichkolwiek innych. W dziedzinie żywienia oznacza praktykę niekorzystania z produktów pochodzących całkowicie lub częściowo od zwierzą̧”21. W uzupełnieniu, definicja wskazuje również, że weganizm nie jest wyłącznie unikaniem określonych zachowań i produktów krzywdzących

20. Kwestia definicji weganizmu jest obiektem dyskusji, ale dla niniejszych rozważań wystarczy definicja The Vegan Society.

21. The Vegan Society, Definition of veganism, <https://www.vegansociety.com/go-vegan/ definition-veganism> (31.10.2018). 
zwierzęta, ale jest również związany z zachęcaniem do aktywności na rzecz ludzi, zwierząt i środowiska naturalnego - poprzez rozwój i używanie alternatyw niepochodzących od zwierząt. Definicja zawiera więc aspekt negatywny (powstrzymanie się od określonego działania) i pozytywny (zachęta do określonego działania). Warto podkreślić, że jest ujęta w szeroki sposób, również w tym sensie, że wskazuje na problematyczność wszystkich produktów zwierzęcych związanych z eksploatacją i okrucieństwem, a nie tylko produktów spożywczych. Co więcej: dotyczy ona nie tylko produktów, ale i praktyk, które są krzywdzące dla zwierząt.

Kluczową w kontekście niniejszych rozważań częścią definicji jest zastrzeżenie o warunkowości weganizmu - mówi o tym formuła „na ile to możliwe i wykonalne” (possible and practicable). Mowa jest o weganizmie jako dynamicznym procesie dążenia do określonego stanu, zabiegania o niego, starania się o jego realizację. Oczywiście formuła ta oznaczała w praktyce co innego w momencie, gdy powstało słowo „weganizm” (lata czterdzieste XX wieku) lub gdy tworzono przywoływaną definicję, a co innego oznacza współcześnie. Możliwości praktykowania weganizmu, przynajmniej w krajach rozwiniętych, wraz z rosnąca popularnością i akceptacją weganizmu, były stopniowo coraz większe. Dziś praktyka ta w wielu miejscach na świecie nie jest już kłopotliwa. Jednak niezależnie od zmiennych możliwości, zasada pozostawała ta sama - weganizm był $i$ jest rozumiany jako „robienie, co się da”, a nie bezwzględny nakaz określonego zachowania w każdej sytuacji i czasie.

\section{Weganizm a reduktarianizm}

Jeśli reduktarianizm rozumiany był jako ograniczenie korzystania z produktów zwierzęcych, a nie tylko spożywania, weganizm daje się przy pewnych zastrzeżeniach nazwać jedną z jego form. Wynika to $\mathrm{z}$ analizowanej wcześniej definicji weganizmu: jest on rozumiany jako dążenie do wykluczenia takich produktów. Wykluczenie to nie może być zupełne - taka jest rzeczywistość. Substancje pochodzenia zwierzęcego znajdują się w wielu produktach, z których wszyscy korzystają na co dzień, a których skład nie jest jawny. Weganie nie mają możliwości odmówić korzystania z takich produktów - nie mają odpowiedniej wiedzy o nich, ale również alternatyw zgodnych z ich systemem etycznym. Słowem: w wielu przypadkach nie mogą dokonać wegańskiego wyboru. Dobrym przykładem ilustrującym ten problem jest papier. Trudno by było całkowicie porzucić korzystanie z niego, chociaż może zawierać substancje pochodzenia zwierzęcego. Z podobną sytuacją mamy do czynienia w przypadku leków oraz w wielu innych przypadkach produktów złożonych. W rzeczywistości więc weganie skupiają się na najbardziej oczywistych przypadkach produktów zwierzęcych lub takich, które zawierają substancje pochodzenia zwierzęcego. Wydaje się to pragmatycznym 
i rozsądnym wyborem, a przeciwna postawa - związana z drobiazgową analizą produktów i odrzuceniem ich nawet, gdy zawierają wyłącznie śladowe ilości substancji zwierzęcych, zwana ingredientyzmem ${ }^{22}$ - jest coraz częściej krytykowana w łonie samego ruchu wegańskiego. Postawę tę daje się krytykować w odniesieniu do definicji The Vegan Society, która jest realistyczna i dobrze rozpoznaje opisywane uwarunkowania weganizmu, stąd właśnie formuła w postaci zastrzeżenia: "na ile to możliwe i wykonalne”. Zastrzeżenie to sugeruje, że weganizm jest reduktarianizmem - formą ograniczenia produktów zwierzęcych, a nie wykluczenia.

Sprawa nie jest jednak tak prosta. W sposobie definiowania i opisywania reduktarianizmu przez same środowisko reduktarian znajdujemy kilka przeszkód, utrudniających uznanie weganizmu za reduktarianizm. Jedną z nich jest stwierdzenie, że dana osoba może być reduktarianinem niezależnie od stopnia, w którym redukuje konsumpcję produktów zwierzęcych, co wyraźnie jest zaznaczone na stronie internetowej ${ }^{23}$, ale wynika również z zawartości Manifestu. Jakkolwiek podaje się różne przykłady postaw reduktariańskich, jak niejedzenie mięsa w poniedziałki (Meatless Mondays), weekendowy wegetarianizm, dzienna dieta polegająca na wegańskim śniadaniu i obiedzie, ale niewegańskiej kolacji (Veganism Before Six) oraz wegetarianizm i weganizm, to dopuszcza się jeszcze skromniejsze ograniczenie. W Manifeście czytamy, że reduktarianinem może być każdy, kto ogranicza ilość produktów zwierzęcych w diecie, nie ma podanego konkretnego progu, po przekroczeniu którego staje się reduktarianinem. $\mathrm{Z}$ tego typu ujęcia reduktarianizmu (które jest częste w materiałach fundacji) wynika, że reduktarianinem może być zarówno osoba, która raz na miesiąc świadomie zje tofucznicę zamiast jajecznicy, nie zmieniając nic innego w diecie, jak i ktoś, kto w 99 procentach konsumuje produkty roślinne. Określona w ten sposób, wspólnota reduktarian wydaje się absurdalnie pojemna. Zawiera nawet te postawy, które nie mają żadnego wymiernego wpływu na rzeczywistość w jej aspekcie ekologicznym, etycznym i zdrowotnym oraz w praktyce są nie do odróżnienia od postawy niereduktariańskiej (zero ograniczeń). To po prostu zbyt szeroka kategoria zachowań i przekonań, żeby dało się znaleźć wyraźny wspólny mianownik, nie mówiąc o zbudowaniu określonej tożsamości zbiorowej. Innymi słowy: to kategoria niewiarygodna, zbyt ogólna i wypełniona nadmiernie różnorodnymi elementami, a więc podatna na krytykę i niefunkcjonalna.

Gdzieniegdzie spotykamy inne, choć niejasne ujęcia reduktarianizmu. Na jednej z podstron napisano, że „Brian uważa, że poprzez wyeliminowanie co najmniej 10

22. Matt Ball, Na ile to jest wegańskie? Składniki a Aktywizm, przeł. Adam Gac, <https://web. archive.org/web/20101223143507/http://empatia.pl/str.php?dz=91\&id=740> (strona zarchiwizowana) (31.10.2018).

23. Zob. choćby: <https://reducetarian.org/faq $>$. 
procent mięsa z naszej diety, osiągniemy wspaniałe osobiste korzyści zdrowotne i przyczynimy się do zdrowszej planety" ${ }^{24}$. Nie brzmi to jednak jak bezwzględne zalecenie, raczej jak stwierdzenie. Poza tym, mowa jest tylko o mięsie. W innym miejscu czytamy: „Kreślimy wizję świata, w którym spożycie czerwonego mięsa, drobiu, owoców morza, jaj i przetworów mlecznych znacznie się zmniejszy ${ }^{25}$. Jednak można sądzić, że chodzi tu o określenie celu, a nie środków, które mają do niego prowadzić. I odnosi się raczej do danych ogólnospołecznych. Zgodę na nawet niewielką redukcję jako przepustkę do reduktariańskiej społeczności potwierdza natomiast uwaga o tym, że reduktarianizm jest czym innym niż fleksitarianizm, a więc jest czym innym niż dieta oparta głównie na roślinach ${ }^{26}$. Czy można sensownie uznać, że istnieje jeden ruch społeczny, którego członkowie redukują korzystanie z produktów zwierzęcych w 1 procencie i w 99 procentach? Innymi słowy: czy jest sensowne nazywanie weganizmu formą reduktarianizmu, skoro prawie wszystko da się w ten sposób nazwać?

W podobnym sensie problematyczne jest także zawarte w Manifeście i na stronie internetowej fundacji stwierdzenie, że reduktarianinem można być niezależnie od przyjętej motywacji. Znów: jest to zbyt szerokie ujęcie, by dało się wyodrębnić konkretną grupę osób złączonych jedną ideą lub podobną praktyką. Takie ujęcie sprawia, że reduktarianinem jest również ktoś, kto powinien - choć wolałby, żeby było inaczej - z przyczyn zdrowotnych (choćby alergia) ograniczyć jedzenie wybranego produktu zwierzęcego, na przykład jakiegoś rodzaju mięsa. Czy można mówić tu o jakimś wspólnym mianowniku z weganizmem? Niemal nieograniczona inkluzywność reduktarianizmu utrudnia uznanie weganizmu za pokrewną postawę.

Interesujące jest to, że w materiałach fundacji znajdujemy w kilku miejscach niepozostawiające wątpliwości stwierdzenie, że weganizm jest częścią reduktarianizmu. „Weganie i wegetarianie są również reduktarianami, ponieważ zredukowali swoją konsumpcję mięsa (tak efektywnie, że w ogóle go nie jedzą)" - czytamy na podstronie $\mathrm{z}$ odpowiedziami na najczęściej zadawane pytania. To stwierdzenie ma sens tylko przy założeniu, że reduktarianizm jest definiowany wąsko (redukcja tylko mięsa), jest to więc pewnie pozostałość po początkowym stadium jego ewolucji. Na stronie głównej można zauważyć sensowniejszą wariację tego motywu: „reduktarianizm obejmuje wegan, wegetarian i każdego, kto zmniejsza ilość produktów pochodzenia zwierzęcego w swojej diecie”. Na wspomnianej wcześniej liście różnych form/stadiów reduktarianizmu (bezmięsny poniedziałek i inne) również widnieje weganizm. Najciekawsza jednak wydaje się odpowiedź

24. <https://reducetarian.org/cookbook>.

25. <https://reducetarian.org/what $>$.

26. <https://reducetarian.org/faq $>$. 
na jedno z najczęściej zadawanych pytań: „Czy reduktarianizm promuje wegetarianizm lub weganizm?". Odpowiedź sformułowana jest w następujący, wymijający sposób: „Reduktarianizm może z pewnością wspomóc niektóre osoby w ograniczeniu ich konsumpcji produktów zwierzęcych do zera! Inni mogą ich jeść po prostu mniej”. Oczywiście fakt, że weganizm nie jest traktowany przez reduktarian jako wyróżniona forma reduktarianizmu, sam w sobie nie sprawia, że weganizm nie może być reduktarianizmem. Wypada jednak zastanowić się, czy jego podkreślana opcjonalność, połączona z bardzo specyficzną i wyraźnie negatywną charakterystyką, o której wspominałem wcześniej, daje podstawy do wątpienia, na ile weganizm jest rzeczywiście jego chcianą częścią. Nie ma podstaw, aby uznać, że weganizm jest oceniany jednoznacznie negatywnie, jednak znacząco często pojawia się jego charakterystyka jako kłopotliwego sąsiada. Szczególnie, że trudno trafić w polityce informacyjnej The Reducetarian Fundation na ślady wizji reduktariańskiego świata, która byłaby choćby zbliżona do wegańskiej wizji. Weganie dążą przecież do wykluczenia wszystkich form eksploatacji i okrucieństwa wobec zwierząt. Znamienne jest, że weganizm jest postrzegany przez opisywanych reduktarian jako forma wykluczenia (redukcji do zera) konsumpcji produktów zwierzęcych. Sam weganizm, co wykazałem wcześniej, tak siebie nie postrzega. Można zapytać, czy włączanie weganizmu do reduktarianizmu dokonywane z takich pozycji ma sens, skoro włączany jest błędnie rozumiany.

\section{Argumenty na rzecz wyodrębnienia weganizmu}

Czy po przeprowadzeniu dotychczasowej analizy da się utrzymać dwuelementową klasyfikację postaw związanych z ograniczeniem korzystania z produktów zwierzęcych, składającą się z reduktarianizmu i weganizmu? Przy opisanych wyżej zawiłościach różnych aspektów relacji reduktarianizmu do weganizmu (i reduktarian do wegan) trudno jest jednoznacznie zgodzić się na uznanie weganizmu za reduktarianizm. O tę kwestię można jednak pytać na różne sposoby: czy weganizm jest częścią reduktarianizmu, czy mógłby być, czy powinien być oraz jaką częścią powinien być. Być może pierwsze z wymienionych pytań nie jest najważniejsze, szczególnie w obliczu plastyczności wciąż młodej definicji reduktarianizmu. Odpowiedź na drugie pytanie wydaje się twierdząca: przy założeniu między innymi uściślenia definicji reduktarianizmu w sposób, który sugerowałem, jest to możliwe. Na pytanie trzecie i czwarte odpowiem zbiorczo: o ile reduktarianizm zacznie być definiowany jako znaczące i dobrowolne ograniczenie produktów pochodzenia zwierzęcego, weganizm powinien zostać uznany za jego szczególną, wyróżnioną w klasyfikacji odrębną nazwą, formę. Powodem, dla którego uważam weganizm 
za bardzo szczególny przypadek tak rozumianego reduktarianizmu, jest przede wszystkim jego wyjątkowa dla różnych form reduktarianizmu (lub stadiów, jeśli założymy, że ograniczenie powinno postępować) intencja wykluczenia (redukcji do zera) korzystania z produktów zwierzęcych. Ta intencja decyduje o specjalnym statusie weganizmu. Jego uznanie ułatwiłoby samym weganom określanie się mianem reduktarian, choć rozumiem, że uznanie to - kłopotliwe dla wielu reduktarian niewegan - wiązałoby się z uznaniem wartości, które stoją za weganizmem. Skoro jednak odpowiadam na pytanie o powinność, proponuję zmianę oceny weganizmu jako punktu odniesienia, względem tej, którą opisałem wcześniej. Weganizm powinien być wyraźnie pozytywnym punktem odniesienia dla reduktarianizmu - jako próba rozsądnej (nie ingredientystycznej) maksymalizacji ograniczenia udziału w krzywdzeniu zwierząt. Jako taki byłby punktem orientacyjnym i motywatorem, atraktorem, ku któremu postępuje ogólny (wychodzący poza sam weganizm) proces redukcji korzystania z produktów zwierzęcych. Wyraźne istnienie pozytywnego opisu weganizmu w materiałach podobnych do analizowanych w tym artykule uświadamiałoby odbiorców i dowodziło możliwości bardzo znacznej redukcji poszerzałoby to, co możliwe do wyobrażenia. Weganizm miałby w tych relacjach niezwykle istotną rolę do odegrania, byłby ważną częścią mechanizmu zachęcania do bardziej znaczącego ograniczenia. To ważne, jeśli w ramach reduktarianizmu zakłada się sporą dowolność ograniczania. Upowszechnienie weganizmu byłoby więc korzystne również pod tym względem. To właśnie liczba wegan i weganek w społeczeństwie może w dużym stopniu określać, która forma ograniczenia będzie uznawana za wartościową. Jak zauważyłem gdzie indziej:

lepiej, żeby ci, którzy ograniczają, a więc są reduktarianami, porównywali się raczej ze stosunkowo licznymi weganami, a nie zupełnie bezrefleksyjnymi i wyraźnie dominującymi wszystkożercami. Niech widzą swoje ograniczenie przez pryzmat rozpowszechniającego się weganizmu. Obecność wegan podwyższa standardy ${ }^{27}$.

Oczywiście, warunkiem podwyższania standardów reduktarianizmu przez weganizm jest pilnowanie przez wegan i weganki jak najwyższych standardów samego weganizmu. Jednym z kryteriów oceny jest jego realizm, którego częścią musi być akceptacja stopniowalności ograniczenia korzystania z produktów zwierzęcych jako nieuchronnego we współczesnym świecie. Innymi słowy: sam weganizm musi być mądrze protopijny.

27. Dariusz Gzyra, Jaś Kapela, W byciu weganinem nie ma nic heroicznego, $<\mathrm{http}: / / \mathrm{krytykapo-}$ lityczna.pl/kultura/czytaj-dalej/gzyra-w-byciu-weganinem-nie-ma-nic-heroicznego > (31.10.2018). Por. Dariusz Gzyra, Agnieszka Olszak, 5 pytań do Dariusza Gzyry, autora książki „Dziękuje za świńskie oczy", <https://www.otwarteklatki.pl/5-pytan-do-dariusza-gzyry-autora-ksiazkidziekuje-za-swinskie-oczy> (31.10.2018). 